Vegetalika. 2017. 6(3): 12-23

\title{
Pengaruh Jarak Tanam Bibit Asal Mata Tunas Tunggal terhadap Pertumbuhan dan Hasil Lima Klon Tebu (Saccharum Officinarum L.) pada Vertisol Lahan Kering
}

\section{The Effect of Plant Spacing with Seedling from Single Bud Chips on Growth and Yield of Five Sugarcane (Saccharum Officinarum L.) Clones on Vertisol Dry land}

\author{
Imam Nur Huda ${ }^{1)}$, Tohari $^{\left.2^{*}\right)}$, Taryono $^{2)}$ \\ 1) Program Studi Agronomi, Fakultas Pertanian, Universitas Gadjah Mada \\ 2) Departemen Budidaya Pertanian, Fakultas Pertanian, Universitas Gadjah Mada \\ *) Penulis untuk korespodensi E-mail: toharidp@gmail.com
}

\begin{abstract}
The cultivation of sugarcane in vertisol dry land is one of effort to increase the production of sugarcane as sugar raw material. The cultivation of sugarcane in vertisol dryland requires special method withtransplanting system using single bud seedling and plant spacing., Plant spacing affects the competition between plants using nutrient, water, sunlight, and growing space. Another important factor is the selection of clones. This research was conducted to determine the best plant spacing of a clone in the transplanting system of sugarcane from single bud chips on vertisol dryland. The experiment was conducted in Dengok Village, Playen District, Gunung Kidul Regency of Yogyakarta Special Region from November 2014 to September 2015. The treatmentsconsists of 2 factors : plant spacing and clones. The plant spacing factor consists of four levels: (1) $30 \mathrm{~cm} \times 100 \mathrm{~cm}$; (2) $45 \mathrm{~cm} \times 100 \mathrm{~cm}$; (3) $60 \mathrm{~cm} \times 100 \mathrm{~cm}$; and (4) $75 \mathrm{~cm} \times 100 \mathrm{~cm}$. The sugarcane clone factor consists of five levels: (1) Bululawang, (2) Kidang Kencana (3) PS 864, (4) PS 881, and (5) VMC. The treatmentsare arranged in a randomized complete block design. The observed data were analyzed using variance analysis, and if there was real difference, a further test of Scott-Knott was done with a 5\%. There is no interaction between clones with plant. The best cultivation of sugarcane on vertisol dryland with seedlingfrom single bud chips using PS 881 and $30 \mathrm{~cm} \times 100 \mathrm{~cm}$ plant spacing.

Keyword : vertisol dryland, plant spacing, clone, growth, yield
\end{abstract}

\section{INTISARI}

Budidaya tebu pada vertisol lahan kering merupakan upaya untuk meningkatkan produksi tebu sebagai bahan baku gula pasir. Budidaya tebu lahan kering memerlukan cara khusus dengan sistem pindah tanam menggunakan bibit asal mata tunas tunggal serta pengaturan jarak tanam. Jarak tanam mempengaruhi persaingan antar tanaman pada penggunaan unsur hara, air, penyerapan cahaya matahari, dan ruang tumbuh. Faktor lain yang perlu diperhatikan pada budidaya tebu lahan kering yaitu pemilihan klon yang ditanam. Penelitian ini dilaksanakan untuk mengetahui jarak tanam terbaik suatu klon pada sistem pindah tanam bibit tebu asalmata tunas tunggal pada vertisol lahan kering. Percobaan dilakukan di Desa Dengok Kecamatan Playen Kabupaten Gunung Kidul Daerah Istimewa Yogyakarta pada bulan November 2014 sampai 
September 2015.Perlakuan tersusun oleh 2 faktor yaitu jarak tanam dan klon. Faktor jarak tanam terdiri dari empat aras: (1) $30 \mathrm{~cm} \times 100 \mathrm{~cm}$; (2) $45 \mathrm{~cm} \times 100 \mathrm{~cm}$; (3) $60 \mathrm{~cm}$ x $100 \mathrm{~cm}$; dan (4) $75 \mathrm{~cm} \times 100 \mathrm{~cm}$. Faktor klon tebu terdiri dari lima aras: (1) Bululawang, (2)Kidang Kencana, (3) PS 864, (4)PS 881, dan (5)VMC. Perlakuan disusun dengan rancangan acak kelompok lengkap. Data pengamatan dianalisis menggunakan sidik ragam, apabila terdapat beda nyata dilakukan uji lanjut Scott-Knott dengan a 5\%.Tidak terjadi interaksi antara klon dengan jarak tanam yang digunakan pada budidaya tebu dengan bibit asal mata tunas tunggal pada vertisol lahan kering. Budidaya tebu pada vertisol lahan kering dengan bibit asal mata tunas tunggal paling baik menggunakan klon PS 881 dan jarak tanam $30 \mathrm{~cm}$ x $100 \mathrm{~cm}$.

Kata kunci : vertisol lahan kering, jarak tanam, klon,pertumbuhan, hasil

\section{PENDAHULUAN}

Gula pasir termasuk salah satu dari sembilan bahan pokok yang dibutuhkan masyarakat. Ketersediaan gula pasir di pasaran sangat penting bagi masyarakat. Jika terjadi kelangkaan akan terjadi kenaikan harga. Kenaikan harga gula pasir berimbas pada menurunnya daya beli masyarakat, kenaikan biaya produksi industri makanan dan minuman yang berbahan baku gula pasir. Jika pemenuhan kebutuhan gula nasional terus menerus dicukupi dengan impor maka ketahanan pangan akan terganggu. Pada akhirnya hal ini akan mempengaruhi ketahanan nasional bangsa.

Produksi gula pasir Indonesia hanya 1,68 \% dibandingkan dengan produksi dunia, sedangkan konsumsi gula pasir Indonesia mencapai 2,79 \% dibandingkan konsumsi dunia. Konsumsi gula pasir Indonesia hampir dua kali lebih banyak dibandingkan kemampuan produksi. Produksi gula pasir Indonesia hanya sekitar $30 \%$ dari total produksi gula pasir Thailand yang sekarang mengekspor gula pasir setiap tahun sekitar dua kali lipat lebih dari kebutuhan nasionalnya Seiring dengan peningkatan konsumsi gula nasional yang diperkirakan mencapai 5,7 juta ton pada tahun 2014, maka akan terjadi perbedaanketersediaan gula pasir dibandingkan kebutuhan gula pasir akibat produksi gula pasir dalam negeri kurang mencukupi (Hakim,2010).

Strategi swasembada gula pasir dilakukan dengan intensifikasi dan ekstensifikasi budidaya tebu sebagai bahan baku gula pasir. Salah satu upaya ekstensifikasi yang dilakukan adalah budidaya tebu di lahan kering. Luasan tebu di lahan kering sebesar $65 \%$ luas lahan tebu nasional. Luas areal penanaman tebu di Indonesia saat ini cukup luas yaitu 476.735 ha dengan produktivitas rata-rata 76,5 ton/ha . Indonesia memiliki daratan sekitar 188,20 juta ha, terdiri atas 148 juta ha lahan 
kering (78\%) dan 40,20 juta ha lahan basah (22\%), sehingga peluang perluasan areal tanam masih dimungkinkan (Anonim, 2001).

Bibit untuk budidaya tebu di lahan kering sebaiknya menggunakan bibit mata tunas tunggal. Menurut Purlani et al. (2015) bibit tebu asal mata tunas tunggal setelah dipindahkan kelahan mampu membentuk anakan 10-20 anakan. Anakan tersebutakan tumbuh sempurna sampai panen 8-10 batang per rumpun, sedangkan bibit dari bagal anakan yang terbentuk 1-4 anakan saja. Bibit asal mata tunas tunggalmembentuk anakan serempak pada umur 1-3 bulan. Pertumbuhan tanaman tebu sejak awal seragam menjadikan tingkat kemasakan tebu dilahan seragam, mampu meningkatkan rendemen dan hasil persatuan luas tanam.

Jarak tanam dapat mempengaruhi produktivitas tebu. Jarak tanam mempengaruhi persaingan antar tanaman pada penggunaan unsur hara, air, cahaya matahari, dan ruang tumbuh. Jarak tanam yang terlalu rapat akan menyebabkan persaingan yang sangat tinggi, mengganggu pertumbuhan tanaman dan menurunkan hasil. Jarak tanam yang terlalu lebar akan menurunkan hasil tanaman karena populasi tidak optimal serta memudahkan gulma tumbuh.

Penggunaan klon yang tepat juga dapat meningkatkan produktivitas tebu. Setiap klon tebu mempunyai ciri, daya hasil, dan syarat tumbuh masing-masing. Ada tebu yang sesuai di lahan yang banyak tersedia air, ada klon tebu yang sesuai untuk lahan kering. Ada juga klon tebu yang tumbuh di tanah bertekstur berat, ada pula klon tebu yang hanya tumbuh di tanah yang bertekstur ringan.

Berdasarkan hal-hal diatas maka penelitian ini berusaha mengetahui jarak tanam terbaik serta mengetahui penggunaan klon yang tepat pada vertisol lahan kering supaya didapatkan hasil yang maksimal.

\section{BAHAN DAN METODE}

Percobaan dilakukan di Desa Dengok Kecamatan Playen Kabupaten Gunung Kidul Daerah Istimewa Yogyakarta pada bulan November 2014 sampai September 2015. Bahan yang digunakan meliputi bibit tebu asal mata tunas tunggalsebanyak lima klon: Bululawang, Kidang Kencana,PS864, PS881, danVMC, pupuk kimia: ZA, KCl dan SP36; media pembibitan: tanah dan kompos; kertas label dan papan kayu.Alat yang digunakan meliputi polibag ukuran (12 cm x 15cm), bud chipper, penggaris, meteran, jangka sorong; timbangan meja, timbangan analitik, kamera digital, danleaf area meter.

Perlakuan tersusun oleh 2 faktor yaitu jarak tanam dan klon. Faktor jarak tanam terdiri dari empat aras: (1) $30 \mathrm{~cm} \times 100 \mathrm{~cm}$; (2) $45 \mathrm{~cm} \times 100 \mathrm{~cm}$; (3) $60 \mathrm{~cm} \times 100 \mathrm{~cm}$; 
dan (4) $75 \mathrm{~cm} \times 100 \mathrm{~cm}$. Faktor klon tebu terdiri dari lima aras: (1) Bululawang, (2)Kidang Kencana, (3) PS 864, (4)PS 881, dan (5)VMC. Perlakuan selanjutnya disusun dalam rancangan acak kelompok lengkap, sehingga terdapat 20 kombinasi perlakuan yang diulang 4 kali. Ukuran petak per unit perlakuan $7 \mathrm{~m} \times 10 \mathrm{~m}$.

Kegiatan yang dilaksanakan dalam penelitian ini meliputi persiapan pembibitan, pindah tanam ke lapangan, pemeliharaan tebu, panen, pengamatan dan pengumpulan data. Pengamatan dan pengumpulan data dilakukan terhadap tinggi tanaman, diameter batang, jumlah ruas, jumlah anakan, luas daun, bobot segar tanam, bobot kering tanaman, brix, rendemen dan hasil tebu yang dipanen.

Data pengamatan agronomis dianalisis ragam dengan rancangan acak kelompok lengkap faktorial. Apabila hasil sidik ragam perlakuan menunjukkan interaksi nyata, maka jarak tanam terbaik setiap klon ditentukan dengan pendekatan regresi untuk masing-masing klon, sedangkan apabila interaksinya tidak nyata tetapi faktor klon dan atau jarak tanam berbeda nyata, maka perbedaan antar klon dan atau jarak tanam dilakukan dengan uji Scott-Knott dengan a $5 \%$.

\section{HASIL DAN PEMBAHASAN}

Pertumbuhan dan hasil tebu pada penelitian ini diukur dengan melakukan pengamatan pada tinggi tanaman, diameter batang, jumlah ruas, jumlah anakan, luas daun, bobot segar, bobot kering, rendemen, brix, derajat pol dan produktivitas tebu.

Hasil sidik ragam menunjukkan bahwa jarak tanam tidak memberikan pengaruh nyata terhadap tinggi tanaman. Hanya perlakuan klon yang memberikan pengaruh nyata dan tidak ada interaksi antara perlakuan jarak tanam dan klon yang digunakan. Hal ini menunjukkan penggunaan suatu klon tidak memerlukan jarak tanam khusus. Klon PS 864 merupakan jenis klon yang paling tinggi, dan Klon Kidang Kencana, Bululawang, PS 881 tidak berbeda nyata dan ketiganya merupakan jenis klon dengan tinggi sedang dan VMC merupakan klon paling rendah (Tabel 1). 
Imam Nur Huda et al., / Vegetalika. 2017. 6(3): 12-23

Tabel 1. Tinggi tebu umur 9 bulan setelah pindah tanam

\begin{tabular}{lccccc}
\hline \multirow{2}{*}{ Klon } & \multicolumn{3}{c}{ Tinggi Tebu pada Jarak Tanam $(\mathrm{cm})$} & \multirow{2}{*}{ Rerata } \\
\cline { 2 - 5 } & $30 \times 100$ & $45 \times 100$ & $60 \times 100$ & $75 \times 100$ & \\
\hline Bululawang & 251,88 & 256,25 & 241,13 & 223,38 & $243,38 \mathrm{~b}$ \\
Kidang Kencana & 243,38 & 257,75 & 244,88 & 243,75 & $247,69 \mathrm{~b}$ \\
PS 864 & 276,50 & 281,88 & 266,88 & 282,00 & $277,00 \mathrm{a}$ \\
PS 881 & 247,00 & 239,50 & 241,25 & 244,13 & $243,13 \mathrm{~b}$ \\
VMC & 218,13 & 230,63 & 238,25 & 231,75 & $230,00 \mathrm{c}$ \\
\hline Rerata & $247,55 \mathrm{a}$ & $253,45 \mathrm{a}$ & $246,80 \mathrm{a}$ & $245,15 \mathrm{a}$ & $(-)$ \\
\hline Nilai CV (\%) & \multicolumn{4}{c}{} & 6,51 \\
\hline Keterangan: Tanda (- ) menunjukkan tidak ada interaksi. Rerata dalam satu baris atau kolom \\
\multicolumn{4}{c}{ yang diikuti oleh huruf yang sama menunjukkan tidak berbeda nyata pada Uji } \\
\multicolumn{4}{l}{ Scott-Knott dengan a 5\%. }
\end{tabular}

Hasil sidik ragam menunjukkan tidak ada interaksi antara jarak tanam dengan klon yang digunakan. Meskipun begitu klon yang digunakan dan jarak tanam memberikan pengaruh nyata terhadap diameter tebu.Klon PS 864 dan Klon PS 881 tidak berbeda nyata menghasilkan diameter batang tebu yang besar, sedangkan Klon Bululawang, Kidang Kencana, dan VMC yang ketiganya tidak saling berbeda nyata menghasilkan tebu dimeter batang yang lebih kecil. Jarak tanam $30 \mathrm{~cm} \times 100 \mathrm{~cm}$ menghasilkan diameter batang yang kecil, sedangkan jarak tanam $45 \mathrm{~cm} \times 100 \mathrm{~cm}, 60$ $\mathrm{cm} \times 100 \mathrm{~cm}$, dan $75 \mathrm{~cm} \times 100 \mathrm{~cm}$ tidak saling berbeda nyata menghasilkan tebu dengan diameter batang yang lebih besar (Tabel 2).

Tabel 2. Diameter batang tebu umur 9 bulan setelah pindah tanam

\begin{tabular}{lccccc}
\hline \multirow{2}{*}{ Klon } & \multicolumn{3}{c}{ Diameter Batang Tebu pada Jarak Tanam $(\mathrm{cm})$} & \multirow{2}{*}{ Rerata } \\
\cline { 2 - 5 } & $30 \times 100$ & $45 \times 100$ & $60 \times 100$ & $75 \times 100$ & \\
\hline Bululawang & 2,61 & 2,69 & 2,84 & 2,76 & $2,75 \mathrm{~b}$ \\
Kidang Kencana & 2,50 & 2,88 & 2,86 & 2,78 & $2,73 \mathrm{~b}$ \\
PS 864 & 2,76 & 2,88 & 2,96 & 2,86 & $2,87 \mathrm{a}$ \\
PS 881 & 2,75 & 2,90 & 2,88 & 2,88 & $2,85 \mathrm{a}$ \\
VMC & 2,59 & 2,76 & 2,81 & 2,99 & $2,79 \mathrm{~b}$ \\
\hline Rerata & $2,64 \mathrm{~b}$ & $2,82 \mathrm{a}$ & $2,87 \mathrm{a}$ & $2,85 \mathrm{a}$ & $(-)$ \\
\hline Nilai CV (\%) & & & & 5,39 \\
\hline
\end{tabular}

Keterangan: Tanda ( - ) menunjukkan tidak ada interaksi. Rerata dalam satu baris atau kolom yang diikuti oleh huruf yang sama menunjukkan tidak berbeda nyata pada Uji Scott-Knott dengan a $5 \%$.

Hasil sidik ragam menunjukkan tidak ada interaksi antar klon yang digunakan dengan jarak tanam. Jarak tanam juga tidak mempengaruhi jumlah ruas tebu yang terbentuk. Meskipun begitu, penggunaan klon tertentu memberikan pengaruh nyata terhadap jumlah ruas yang terbentuk. 
Tabel 3. Jumlah ruas tebu umur 9 bulan setelah pindah tanam

\begin{tabular}{lccccc}
\hline \multirow{2}{*}{ Klon } & \multicolumn{2}{c}{ Jumlah Ruas Tebu pada Jarak Tanam $(\mathrm{cm})$} & \multirow{2}{*}{ Rerata } \\
\cline { 2 - 5 } & $30 \times 100$ & $45 \times 100$ & $60 \times 100$ & $75 \times 100$ & \\
\hline Bululawang & 15,63 & 16,13 & 15,25 & 15,00 & $15,63 \mathrm{~b}$ \\
Kidang Kencana & 15,63 & 16,75 & 15,38 & 15,13 & $16,00 \mathrm{~b}$ \\
PS 864 & 17,13 & 16,38 & 17,88 & 17,88 & $17,50 \mathrm{a}$ \\
PS 881 & 15,63 & 15,75 & 15,38 & 15,63 & $15,81 \mathrm{~b}$ \\
VMC & 15,00 & 16,13 & 17,25 & 16,25 & $16,44 \mathrm{~b}$ \\
\hline Rerata & $16,05 \mathrm{a}$ & $16,40 \mathrm{a}$ & $16,45 \mathrm{a}$ & $16,20 \mathrm{a}$ & $(-)$ \\
\hline Nilai CV (\%) & & & & & 8,43 \\
\hline
\end{tabular}

Keterangan: Tanda ( - ) menunjukkan tidak ada interaksi. Rerata dalam satu baris atau kolom yang diikuti oleh huruf yang sama menunjukkan tidak berbeda nyata pada Uji Scott-Knott dengan a $5 \%$.

Klon PS 864 mempunyai jumlah ruas paling banyak, sedangkan klon Bululawang, Kidang Kencana, PS 881, dan VMC tidak berbeda mempunayi jumlah ruas lebih sedikit dan tidak berbeda nyata (Tabel 3 ).

Tabel 4. Jumlah anakan tebu umur 9 bulan setelah pindah tanam

\begin{tabular}{lccccc}
\hline \multirow{2}{*}{ Klon } & \multicolumn{2}{c}{ Jumlah Anakan Tebu pada Jarak Tanam $(\mathrm{cm})$} & \multirow{2}{*}{ Rerata } \\
\cline { 2 - 5 } & $30 \times 100$ & $45 \times 100$ & $60 \times 100$ & $75 \times 100$ & \\
\hline Bululawang & 4,38 & 4,63 & 6,88 & 7,13 & $6,00 \mathrm{a}$ \\
Kidang Kencana & 3,50 & 3,75 & 5,38 & 6,25 & $5,06 \mathrm{~b}$ \\
PS 864 & 3,25 & 4,63 & 5,13 & 7,13 & $5,25 \mathrm{~b}$ \\
PS 881 & 4,00 & 4,38 & 6,00 & 5,25 & $5,19 \mathrm{~b}$ \\
VMC & 3,75 & 6,00 & 7,00 & 6,88 & $6,25 \mathrm{a}$ \\
\hline Rerata & $4,20 \mathrm{~b}$ & $4,90 \mathrm{~b}$ & $6,30 \mathrm{a}$ & $6,80 \mathrm{a}$ & $(-)$ \\
\hline Nilai CV (\%) & & & & 20.78 \\
\hline
\end{tabular}

Keterangan: Tanda ( - ) menunjukkan tidak ada interaksi. Rerata dalam satu baris atau kolom yang diikuti oleh huruf yang sama menunjukkan tidak berbeda nyata pada Uji Scott-Knott dengan a 5\%.

Hasil sidik ragam menunjukkan bahwa tidak ada interaksi antara klon yang digunakan dengan jarak tanam. Meskipun begitu klon dan jarak tanam masing-masing memberikan pengaruh nyata terhadap jumlah anakan yang terbentuk. Klon yang menghasilkan anakan paling banyak yaitu VMC dan Bululawang yang masing-masing tidak saling berbeda nyata. Kemudian jarak tanam yang menghasilkan jumlah anakan paling banyak yaitu $60 \mathrm{~cm} \times 100 \mathrm{~cm}$ dan $75 \mathrm{~cm} \times 100 \mathrm{~cm}$ yang tidak berbeda nyata dan jarak tanam yang menghasilkan jumlah anakan lebih sedikit yaitu $30 \mathrm{~cm} \times 100 \mathrm{~cm}$ dan $40 \mathrm{~cm} \times 100 \mathrm{~cm}$ yang keduanya tidak saling berbeda nyata (Tabel 4). 
Imam Nur Huda et al., / Vegetalika. 2017. 6(3): 12-23

Tabel 5. Luas daun tebu umur 6 bulan setelah pindah tanam $\left(\mathrm{cm}^{2}\right)$

\begin{tabular}{lccccc}
\hline \multirow{2}{*}{ Klon } & \multicolumn{3}{c}{ Luas Daun Tebu pada Jarak Tanam $(\mathrm{cm})$} & \multirow{2}{*}{ Rerata } \\
\cline { 2 - 5 } & $30 \times 100$ & $45 \times 100$ & $60 \times 100$ & $75 \times 100$ & \\
\hline Bululawang & 27165,00 & 26452,50 & 31352,50 & 33445,00 & $29603,75 \mathrm{a}$ \\
Kidang Kencana & 30100,00 & 19320,00 & 30100,00 & 30420,00 & $25910,00 \mathrm{a}$ \\
PS 864 & 21715,00 & 27302,50 & 28082,50 & 38567,50 & $28916,88 \mathrm{a}$ \\
PS 881 & 21782,50 & 26162,50 & 33002,50 & 28807,50 & $27438,75 \mathrm{a}$ \\
VMC & 20340,00 & 23915,00 & 36735,00 & 33997,50 & $28746,88 \mathrm{a}$ \\
\hline Rerata & $22772,00 \mathrm{~b}$ & $25082,50 \mathrm{~b}$ & $31735,50 \mathrm{a}$ & $32903,00 \mathrm{a}$ & $(-)$ \\
\hline Nilai CV (\%) & & & & 22,66 \\
\hline Keterangan: Tanda ( - ) menunjukkan tidak ada interaksi. Rerata dalam satu baris atau kolom \\
\multicolumn{4}{c}{ yang diikuti oleh huruf yang sama menunjukkan tidak berbeda nyata pada Uji } \\
Scott-Knott dengan a 5\%.
\end{tabular}

Hasil sidik ragam menunjukkan tidak ada interaksi antara klon yang digunakan dan jarak tanam. Meskipun begitu jarak tanam yang digunakan memberikan pengaruh nyata terhadap luas daun tebu yang terbentuk. Jarak tanam $60 \times 100 \mathrm{~cm}$ dan $75 \mathrm{~cm} \times$ $100 \mathrm{~cm}$ menghasilkan luas daun yang lebih besar dibandingkan jarak tanam $30 \mathrm{~cm} \times$ $100 \mathrm{~cm}$ dan $45 \mathrm{~cm} \times 100 \mathrm{~cm}$ (Tabel 5).

Tabel 6. Bobot segar tebu umur 9 bulan setelah pindah tanam (g)

\begin{tabular}{lccccc}
\hline \multirow{2}{*}{ Klon } & \multicolumn{3}{c}{ Bobot Segar Tebu pada Jarak Tanam $(\mathrm{cm})$} & \multirow{2}{*}{ Rerata } \\
\cline { 2 - 5 } & $30 \times 100$ & $45 \times 100$ & $60 \times 100$ & $75 \times 100$ & \\
\hline Bululawang & 6576,86 & 7730,94 & 8916,55 & 8527,05 & $7937,85 \mathrm{a}$ \\
Kidang Kencana & 6112,29 & 8005,54 & 8374,00 & 8935,38 & $7856,80 \mathrm{a}$ \\
PS 864 & 7239,35 & 9079,36 & 9539,93 & 10523,90 & $9095,63 \mathrm{a}$ \\
PS 881 & 6394,13 & 7606,03 & 9544,43 & 9575,86 & $8280,11 \mathrm{a}$ \\
VMC & 5577,26 & 9494,71 & 9878,28 & 9776,83 & $8681,77 \mathrm{a}$ \\
\hline Rerata & $6379,98 \mathrm{~b}$ & $8383,32 \mathrm{a}$ & $9250,64 \mathrm{a}$ & $9467,80 \mathrm{a}$ & $(-)$ \\
\hline Nilai CV (\%) & & & & & 23,38 \\
\hline Keterangan: Tanda $(-)$ menunjukkan tidak ada interaksi. Rerata dalam satu baris atau kolom \\
\multicolumn{4}{c}{ yang diikuti oleh huruf yang sama menunjukkan tidak berbeda nyata pada Uji } \\
\multicolumn{4}{c}{ Scott-Knott dengan $\alpha$ 5\%. }
\end{tabular}

Hasil sidik ragam menunjukkan jarak tanam memberikan pengaruh nyata terhadap bobot segar tanaman, sedangkan klon tidak memberikan pengaruh secara nyata terhadap bobot segar tanaman dan tidak terjadi interaksi antara jarak tanam dengan klon. Jarak tanam $45 \mathrm{~cm} \times 100 \mathrm{~cm}, 60 \mathrm{~cm} \times 100 \mathrm{~cm}$ dan $75 \mathrm{~cm} \times 100 \mathrm{~cm}$ menghasilkan tebu dengan bobot segar yang lebih tinggi dibandingkan jarak tanam 30 $\mathrm{cm} \times 100 \mathrm{~cm}$ (Tabel 6).

Hasil sidik ragam menunjukkan bahwa jarak tanam dan klon memberikan pengaruh secara nyata terhadap bobot kering tanaman, meskipun begitu tidak terjadi interaksi antara jarak tanam dan klon. Klon Bululawang, PS 864, PS 881 dan VMC memberikan bobot kering yang lebih besar dibandingkan klon Kidang Kencana. Jarak tanam $75 \mathrm{~cm} \times 100 \mathrm{~cm}$ menghasilkan tebu dengan bobot kering paling besar, jarak tanam $45 \mathrm{~cm} \times 100 \mathrm{~cm}$ dan jarak tanam $60 \mathrm{~cm} \times 100 \mathrm{~cm}$ menghasilkan tebu dengan 
bobot sedang, dan jarak tanam $30 \mathrm{~cm} \times 100 \mathrm{~cm}$ menghasilkan tebu dengan bobot kering paling kecil (Tabel 7).

Tabel 7. Bobot kering tebu umur 9 bulan setelah pindah tanam $(\mathrm{g})$

\begin{tabular}{lccccc}
\hline \multirow{2}{*}{ Klon } & \multicolumn{3}{c}{ Bobot Kering Tebu pada Jarak Tanam $(\mathrm{cm})$} & \multirow{2}{*}{ Rerata } \\
\cline { 2 - 5 } & $30 \times 100$ & $45 \times 100$ & $60 \times 100$ & $75 \times 100$ & \\
\hline Bululawang & 1502,31 & 1721,18 & 1957,38 & 2244,43 & $1856,32 \mathrm{a}$ \\
Kidang Kencana & 1254,60 & 1502,34 & 1551,08 & 1864,86 & $1543,22 \mathrm{~b}$ \\
PS 864 & 1525,86 & 1945,48 & 1767,95 & 2499,45 & $1934,68 \mathrm{a}$ \\
PS 881 & 1641,69 & 1913,00 & 2175,13 & 2556,66 & $2071,62 \mathrm{a}$ \\
VMC & 1277,08 & 1975,15 & 1932,39 & 1922,80 & $1776,85 \mathrm{a}$ \\
\hline Rerata & $1440,31 \mathrm{c}$ & $1811,43 \mathrm{~b}$ & $1876,78 \mathrm{~b}$ & $2217,64 \mathrm{a}$ & $(-)$ \\
\hline Nilai CV $(\%)$ & & & & & 22,58 \\
\hline
\end{tabular}

Keterangan: Tanda ( - ) menunjukkan tidak ada interaksi. Rerata dalam satu baris atau kolom yang diikuti oleh huruf yang sama menunjukkan tidak berbeda nyata pada Uji Scott-Knott dengan a $5 \%$.

Hasil sidik ragam menunjukkan jarak tanam dan klon memberikan pengaruh secara nyata terhadap rendemen tebu di lahan kering vertisol, meskipun begitu tidak terjadi interaksi antara klon dengan jarak tanam yang digunakan. Klon PS 881 dan VMC tidak berbeda nyata menghasilkan rendemen yang paling tinggi, sedangkan klon Bululawang, Kidang Kencana, dan PS 864 tidak berbeda nyata menghasilkan rendemen yang lebih rendah di lahan kering vertisol. Jarak tanam $30 \mathrm{~cm} \times 100 \mathrm{~cm}$ menghasilkan rendemen yang paling tinggi di lahan kering vertisol, sedangkan jarak tanam $45 \mathrm{~cm} \times 100 \mathrm{~cm}$ dan $60 \mathrm{~cm} \times 100 \mathrm{~cm}$ menghasilkan rendemen sedang dengan kedua jarak tanam tersebut tidak berbeda nyata. Jarak tanam $75 \mathrm{~cm}$ x $100 \mathrm{~cm}$ menghasilkan rendemen yang paling rendah (Tabel 8 ).

Tabel 8. Rendemen tebu umur 9 bulan setelah pindah tanam (\%)

\begin{tabular}{lccccc}
\hline \multirow{2}{*}{ Klon } & \multicolumn{3}{c}{ Rendemen Tebu pada Jarak Tanam $(\mathrm{cm})$} & \multirow{2}{*}{ Rerata } \\
\cline { 2 - 5 } & $30 \times 100$ & $45 \times 100$ & $60 \times 100$ & $75 \times 100$ & \\
\hline Bululawang & 8,31 & 7,42 & 7,20 & 6,75 & $7,42 \mathrm{~b}$ \\
Kidang Kencana & 7,64 & 7,55 & 7,38 & 7,09 & $7,42 \mathrm{~b}$ \\
PS 864 & 7,92 & 7,76 & 6,79 & 6,87 & $7,33 \mathrm{~b}$ \\
PS 881 & 8,34 & 7,73 & 7,51 & 7,24 & $7,70 \mathrm{a}$ \\
VMC & 8,33 & 8,01 & 7,42 & 7,22 & $7,74 \mathrm{a}$ \\
\hline Rerata & $8,11 \mathrm{a}$ & $7,69 \mathrm{~b}$ & $7,26 \mathrm{c}$ & $7,03 \mathrm{c}$ & $(-)$ \\
\hline Nilai CV (\%) & & & & & 6,59 \\
\hline
\end{tabular}

Keterangan: Tanda ( - ) menunjukkan tidak ada interaksi. Rerata dalam satu baris atau kolom yang diikuti oleh huruf yang sama menunjukkan tidak berbeda nyata pada Uji Scott-Knott dengan a 5\%. 
Imam Nur Huda et al., / Vegetalika. 2017. 6(3): 12-23

Tabel 9. Brix tebu umur 9 bulan setelah pindah tanam (\%)

\begin{tabular}{lccccc}
\hline \multirow{2}{*}{ Klon } & \multicolumn{3}{c}{ Brix Tebu pada Jarak Tanam $(\mathrm{cm})$} & \multirow{2}{*}{ Rerata } \\
\cline { 2 - 5 } & $30 \times 100$ & $45 \times 100$ & $60 \times 100$ & $75 \times 100$ & \\
\hline Bululawang & 23,63 & 23,79 & 23,83 & 24,00 & $23,81 \mathrm{~b}$ \\
Kidang Kencana & 24,21 & 23,17 & 23,79 & 23,79 & $23,74 \mathrm{~b}$ \\
PS 864 & 23,25 & 23,75 & 23,13 & 23,00 & $23,28 \mathrm{~b}$ \\
PS 881 & 24,58 & 25,46 & 25,00 & 25,83 & $25,22 \mathrm{a}$ \\
VMC & 22,69 & 23,21 & 21,67 & 22,88 & $22,61 \mathrm{c}$ \\
\hline Rerata & $23,67 \mathrm{a}$ & $23,87 \mathrm{a}$ & $23,48 \mathrm{a}$ & $23,90 \mathrm{a}$ & $(-)$ \\
\hline Nilai CV (\%) & & & & 4,54 \\
\hline
\end{tabular}

Keterangan: Tanda ( - ) menunjukkan tidak ada interaksi. Rerata dalam satu baris atau kolom yang diikuti oleh huruf yang sama menunjukkan tidak berbeda nyata pada Uji Scott-Knott dengan a 5\%.

Hasil sidik ragam menunjukkan jarak tanam tidak memberikan pengaruh nyata terhadap brix tebu tetapi klon memberikan pengaruh nyata terhadap brix tebu dan tidak terjadi interaksi antara jarak tanam dengan klon. Tebu yang mempunyai brix tertinggi di lahan kering vertisol yaitu klon PS 881, tebu yang menghasilkan brix sedang di lahan kering vertisol yaitu Bululawang, Kidang Kencana, dan PS 864 yang mana ketiganya tidak saling berbeda nyata dan klon yang menghasilkan brix paling rendah di lahan kering vertisol yaitu klon VMC (Tabel 9).

Tabel 10. Derajat pol tebu umur 9 bulan setelah pindah tanam (\%)

\begin{tabular}{lccccc}
\hline \multirow{2}{*}{ Klon } & \multicolumn{3}{c}{ Derajat Pol pada Jarak Tanam $(\mathrm{cm})$} & \multirow{2}{*}{ Rerata } \\
\cline { 2 - 5 } & $30 \times 100$ & $45 \times 100$ & $60 \times 100$ & $75 \times 100$ & \\
\hline Bululawang & 14,77 & 13,37 & 12,88 & 12,26 & $13,32 \mathrm{a}$ \\
Kidang Kencana & 13,89 & 13,60 & 13,40 & 13,00 & $13,47 \mathrm{a}$ \\
PS 864 & 14,16 & 13,84 & 12,31 & 12,57 & $13,22 \mathrm{~b}$ \\
PS 881 & 15,14 & 13,95 & 13,63 & 13,29 & $14,00 \mathrm{a}$ \\
VMC & 14,84 & 14,33 & 13,49 & 13,18 & $13,96 \mathrm{a}$ \\
\hline Rerata & $14,56 \mathrm{a}$ & $13,82 \mathrm{~b}$ & $13,14 \mathrm{c}$ & $12,86 \mathrm{c}$ & $(-)$ \\
\hline Nilai CV $(\%)$ & & & & & 5,18 \\
\hline
\end{tabular}

Keterangan: Tanda ( - ) menunjukkan tidak ada interaksi. Rerata dalam satu baris atau kolom yang diikuti oleh huruf yang sama menunjukkan tidak berbeda nyata pada Uji Scott-Knott dengan a $5 \%$.

Hasil sidik ragam menunjukkan bahwa klon dan jarak tanam yang digunakan memberikan pengaruh nyata terhadap pol tebu, meskipun begitu tidak terjadi interaksi atara klon dengan jarak tanam. Klon Bululawang, Kidang Kencana, PS 881, dan VMC tidak berbeda nyata memberikan hasil pol tertinggi, sedangkan klon PS 864 menghasilkan pol yang lebih rendah. Jarak tanam $30 \mathrm{~cm} \times 100 \mathrm{~cm}$ memberikan hasil pol tertinggi, jarak tanam $45 \mathrm{~cm} \times 100 \mathrm{~cm}$ menghasilkan pol sedang dan jarak tanam $60 \mathrm{~cm} \times 100 \mathrm{~cm}$ dan $75 \mathrm{~cm} \times 100 \mathrm{~cm}$ yang tidak berbeda nyata menghasilkan pol terendah (Tabel 10). 
Tabel 11. Produktivitas tebu (ton/ha)

\begin{tabular}{lccccc}
\hline \multirow{2}{*}{ Klon } & \multicolumn{3}{c}{ Produktivitas Tebu pada Jarak Tanam $(\mathrm{cm})$} & \multirow{2}{*}{ Rerata } \\
\cline { 2 - 5 } & $30 \times 100$ & $45 \times 100$ & $60 \times 100$ & $75 \times 100$ & \\
\hline Bululawang & 130,26 & 113,02 & 91,94 & 80,59 & $103,95 \mathrm{a}$ \\
Kidang Kencana & 92,85 & 86,85 & 92,75 & 80,78 & $88,31 \mathrm{a}$ \\
PS 864 & 90,70 & 114,94 & 93,33 & 92,86 & $97,96 \mathrm{a}$ \\
PS 881 & 108,92 & 90,68 & 93,44 & 74,71 & $91,94 \mathrm{a}$ \\
VMC & 113,61 & 96,98 & 86,65 & 81,98 & $94,80 \mathrm{a}$ \\
\hline Rerata & $107,27 \mathrm{a}$ & $100,49 \mathrm{a}$ & $91,62 \mathrm{~b}$ & $82,18 \mathrm{~b}$ & $(-)$ \\
\hline Nilai CV $(\%)$ & & & & 21,63 \\
\hline
\end{tabular}

Keterangan: Tanda ( - ) menunjukkan tidak ada interaksi. Rerata dalam satu baris atau kolom yang diikuti oleh huruf yang sama menunjukkan tidak berbeda nyata pada Uji Scott-Knott dengan a $5 \%$.

Hasil sidik ragam menunjukkan bahwa klon tidak memberikan pengaruh nyata terhadap hasil tebu yang dipanen, sedangkan jarak tanam memberikan pengaruh nyata terhadap hasil tebu yang dipanen dan tidak terjadi interaksi antara klon dengan jarak tanam. Jarak tanam $30 \mathrm{~cm} \times 100 \mathrm{~cm}$ dan $45 \mathrm{~cm} \times 100 \mathrm{~cm}$ tidak berbeda nyata memberikan hasil tebu paling tinggi, sedangkan jarak tanam $60 \mathrm{~cm} \times 100 \mathrm{~cm}$ dan 75 $\mathrm{cm}$ yang tidak berbeda nyata memberikan hasil panen yang lebih rendah (Tabel 11).

Hasil merupakan luaran (output) dari pertumbuhan. Pertumbuhan yang baik akan memberikan hasil yang baik, demikian sebaliknya. Pengukuran hasil pada penelitan ini meliputi mutu tebu, yang ditentukan melalui pengukuran brix, rendemen, derajat pol dan produktivitas tebu yang dipanen.

Brix tebu paling tinggi dihasilkan oleh klon PS 881. Hasil analisis regresi menunjukkan bahwa brix $\left(Y_{1}\right)$ dipengaruhi oleh tinggi tanaman $\left(X_{1}\right)$, diameter batang $\left(X_{2}\right)$, bobot segar tebu $\left(X_{3}\right)$, secara kuat dengan koefisien regresi mendekati $1\left(R^{2}=\right.$ $0,99) . Y_{1}=0,0012 X_{1} \cdot 0,33 X_{2} \cdot 0,0000089 X_{3} . \quad(R 2=0,99)$

Brix yang tinggi didapatkan jika tinggi tanaman maksimal, diameter batang maksimal, bobot segar tanaman minimal. Tinggi tanaman yang paling tinggi di hasilkan oleh klon PS 864 dan PS 881. Diameter batang paling besar di hasilkan oleh klon PS 864, PS 881, jarak tanam $45 \mathrm{~cm} \times 100 \mathrm{~cm}$, jarak tanam $60 \mathrm{~cm} \times 100 \mathrm{~cm}$ dan jarak tanam $75 \mathrm{~cm} \times 100 \mathrm{~cm}$. Bobot segar tanaman terendah dihasilkan oleh jarak tanam 30 $\mathrm{cm} \times 100 \mathrm{~cm}$.

Rendemen tertinggi didapatkan dengan menggunakan klon PS 881 dan VMC dengan jarak tanamannya adalah $30 \mathrm{~cm} \times 100 \mathrm{~cm}$. Hasil analisis regresi menunjukkan bahwa rendemen $\left(Y_{2}\right)$ dipengaruhi oleh tinggi tanaman $\left(X_{1}\right)$, diameter batang $\left(X_{2}\right)$, jumlah anakan $\left(X_{3}\right)$, luas daun $\left(X_{4}\right)$, bobot segar tanaman $\left(X_{5}\right)$. Pengaruh bersifat kuat dimana koefisien regresi mendekati $1\left(R^{2}=0,99\right) . \quad Y_{2}=0,00064 X_{1} \cdot 0,24 X_{2} \cdot 0,22 X_{3}$. $0,0000046 X_{4} \cdot 0,000011 X_{5}\left(R^{2}=0,99\right)$ 
Imam Nur Huda et al., / Vegetalika. 2017. 6(3): 12-23

Rendemen tertinggi didapatkan jika tinggi tanaman maksimal, diameter batang maksimal, jumlah anakan maksimal, luas daun minimal, bobot segar minimal. Tinggi tanaman yang paling tinggi di hasilkan oleh klon PS 864 dan PS 881. Diameter batang paling besar di hasilkan oleh klon PS 864, PS 881, jarak tanam $45 \mathrm{~cm} \times 100 \mathrm{~cm}$, jarak tanam $60 \mathrm{~cm} \times 100 \mathrm{~cm}$ dan jarak tanam $75 \mathrm{~cm} \times 100 \mathrm{~cm}$. Jumlah anakan paling banyak dihasilkan oleh klon Bululawang, VMC, jarak tanam $60 \mathrm{~cm} \times 100 \mathrm{~cm}$ dan jarak tanam $75 \mathrm{~cm} \times 100 \mathrm{~cm}$. Luas daun terendah dihasilkan oleh jarak tanam $30 \mathrm{~cm} \times 100$ $\mathrm{cm}$ dan $45 \mathrm{~cm} \times 100 \mathrm{~cm}$. Bobot segar tanaman terendah dihasilkan oleh jarak tanam $30 \mathrm{~cm} \times 100 \mathrm{~cm}$.

Derajat pol paling tinggi didapatkan ketika budidaya tebu menggunakan klon Bululawang, Kidang Kencana, PS 881, VMC, dan jarak tanam $30 \mathrm{~cm}$ x $100 \mathrm{~cm}$. Hasil analisis regresi menunjukkan derajat pol $\left(\mathrm{Y}_{3}\right)$ dipengaruhi variabel pertumbuhan berupa tinggi tanaman $\left(\mathrm{X}_{1}\right)$, diameter batang $\left(\mathrm{X}_{2}\right)$, jumlah anakan $\left(\mathrm{X}_{3}\right)$, luas daun $\left(\mathrm{X}_{4}\right)$, bobot segar tebu $\left(X_{5}\right) . Y_{3}=0,0013 X_{1} \cdot 0,24 X_{2} \cdot 0,017 X_{3} \cdot 0,0000036 X_{4} \cdot 0,0000089 X_{5} .\left(R^{2}=0,99\right)$

Pengaruh varibel $X$ terhadap $Y$ bersifat kuat dimana koefisien regresi mendekati $1\left(R^{2}=0,99\right)$. Derajat pol yang tinggi didapatkan apabila tinggi tanaman maksimal, diameter batang maksimal, jumlah anakan maksimal, bobot segar tebu rendah, luas daun rendah, Tinggi tanaman yang paling tinggi di hasilkan oleh klon PS 864. Diameter batang paling besar di hasilkan oleh klon PS 864, PS 881, jarak tanam $45 \mathrm{~cm} \times 100 \mathrm{~cm}$, jarak tanam $60 \mathrm{~cm} \times 100 \mathrm{~cm}$ dan jarak tanam $75 \mathrm{~cm} \times 100 \mathrm{~cm}$. Jumlah anakan paling banyak dihasilkan oleh klon Bululawang, VMC, jarak tanam 60 $\mathrm{cm} \times 100 \mathrm{~cm}$ dan jarak tanam $75 \mathrm{~cm} \times 100 \mathrm{~cm}$. Luas daun paling kecil dihasilkan oleh jarak tanam $30 \mathrm{~cm} \times 100 \mathrm{~cm}$ dan $45 \mathrm{~cm} \times 100 \mathrm{~cm}$. Bobot segar tebu paling rendah dihasilkan oleh jarak tanam $30 \mathrm{~cm} \times 100 \mathrm{~cm}$.

Produktivitas tebu tertinggi didapatkan jika menggunakan jarak tanam $30 \mathrm{~cm} \mathrm{x}$ $100 \mathrm{~cm}$ dan $45 \mathrm{~cm} \times 100 \mathrm{~cm}$. Hasil analisis regresi menunjukkan bahwa produktivitas tebu $\left(Y_{4}\right)$ dipengaruhi tinggi tanaman $\left(X_{1}\right)$, diameter batang $\left(X_{2}\right)$, jumlah anakan $\left(X_{3}\right)$, luas daun $\left(X_{4}\right)$ dengan pengaruh bersifat kuat dimana koefisien regresi mendekati 1 $\left(R^{2}=0,99\right)$, pesamaannya yaitu: $Y_{4}=0,0016 X_{1} \cdot 0,44 X_{2} \cdot 0,028 X_{3} \cdot 0,0000081 X_{4}\left(R^{2}=\right.$ $0,99)$.

Produktivitas tinggi didapatkan jika tinggi tanaman maksimal, diameter batang maksimal, jumlah anakan maksimal, luas daun minimal, indeks luas daun maksimal dan laju asimliasi bersih tanaman maksimal. Tinggi tanaman yang paling tinggi di hasilkan oleh klon PS 864. Diameter batang paling besar di hasilkan oleh klon PS 864 , PS 881, jarak tanam $45 \mathrm{~cm} \times 100 \mathrm{~cm}$, jarak tanam $60 \mathrm{~cm} \times 100 \mathrm{~cm}$ dan jarak tanam 75 
$\mathrm{cm} \times 100 \mathrm{~cm}$. Jumlah anakan paling banyak dihasilkan oleh klon Bululawang, VMC, jarak tanam $60 \mathrm{~cm} \times 100 \mathrm{~cm}$ dan jarak tanam $75 \mathrm{~cm} \times 100 \mathrm{~cm}$. Luas daun terendah dihasilkan oleh jarak tanam $30 \mathrm{~cm} \times 100 \mathrm{~cm}$ dan $45 \mathrm{~cm} \times 100 \mathrm{~cm}$.

Klon PS 881 mampu menghasilkan brix, rendemen dan derajat pol yang tinggi. Klon PS 881 mampu menghasilkan diamater batang yang besar dan tinggi tanaman yang memadai. Tinggi tanaman dan diameter batang memberikan pengaruh positif terhadap brix, rendemen, derajat pol dan hasil tebu. Jarak tanam $30 \mathrm{~cm} \times 100 \mathrm{~cm}$ memberikan hasil tebu yang paling tinggi dan rendemen yang paling tinggi pula. Jarak tanam $30 \mathrm{~cm} \times 100 \mathrm{~cm}$ mempengaruhi bobot segar dan laju asimilasi bersih yang dapat memberikan pengaruh positif pada brix. Jarak tanam $30 \mathrm{~cm} \mathrm{x} 100 \mathrm{~cm}$ mempengarahui indeks luas daun dan laju pertumbuhan tanaman yang memberikan pengaruh positif terhadap hasil tebu dan gula pasir yang dihasilkan. Jarak tanam 30 cm x $100 \mathrm{~cm}$ memberikan hasil yang baik terhadap luas daun dan indeks luas daun yang memberikan pengaruh positif pada derajat pol. Hal ini menunjukkan bahwa klon PS 881 dan jarak tanam $30 \mathrm{~cm} \times 100$ memberikan pengaruh positif yang paling banyak terhadap pertumbuhan dan hasil tebu pada vertisol lahan kering..

\section{KESIMPULAN}

1. Tidak terjadi interaksi antara klon dengan jarak tanam yang digunakan pada budidaya tebu dengan bibit asal mata tunas tunggal pada vertisol lahan kering.

2. Budidaya tebu pada vertisol lahan kering dengan bibit asal mata tunas tunggal paling baik menggunakan klon PS 881 dan jarak tanam $30 \mathrm{~cm} \times 100 \mathrm{~cm}$.

\section{UCAPAN TERIMAKASIH}

Penulis menyampaikan terima kasih kepada Bapak Bapak Wawan Sulistyono, S.P.,M.P. dan Latiful Muttaqin selaku rekan dalam penelitan ini. Orang tua dan saudara yang telah memberikan dukungan moril dan materil dan Semua pihak yang membantu dalam penyelesaian penelitian ini

\section{DAFTAR PUSTAKA}

Anonim. 2001. Atlas arahan tata ruang pertanian indonesia skala 1:1.000.000. Pusat Penelitian dan Pengembangan Tanah dan Agroklimat, Bogor.

Hakim, M. 2010. Potensi sumber daya lahan untuk tanaman tebu di Indonesia. Jurnal Agrikultura 21 (1):5-12.

Purlani, E., H.P. Diwang, H. Istiana, dan Subiyakto. 2015. Pembenihan tebu bud chips. $<$ http://www.litbang.pertanian.go.id/berita/one/2326/file/Pembenihan-Tebu-Bud Chips.pdf>. Diakses 3 April 2016. 